\title{
The pandemic and the labor market in Brazil
}

\section{Simone da Silva Costa 1}

1 Universidade Federal do Rio Grande do Norte / Department of Architecture and Urbanism, Natal / RN - Brazil

The COVID-19 pandemic is a global public health problem that has given new dynamics to the world economy. The rapid spread of the disease and the use of social distancing as a form of prevention exposed the social and urban inequalities of capitalist cities. In Brazil, as in other countries, social distancing has promoted rapid changes in the labor market with more severe impacts for 37.3 million people living in the informal sector, as they do not have rights to, for example, the severance pay indemnity fund (FGTS) and unemployment benefit. According to the International Labour Organization, the first layoffs are occurring among those who live off precarious work, such as: outsourced workers, clerks, waiters, kitchen workers, day laborers, baggage handlers, and cleaners. We show a brief synthesis of the consequences that the health crisis has brought to Brazilian workers and propose coping measures that are not limited to emergency aid. The recovery and creation of occupations will depend, among other factors, on the resumption of spending on social and economic programs that were able to reduce social inequalities at the beginning of this century, such as PAC-favelas; Minha Casa, Minha Vida Program; Bolsa Família Program and the FAT Employment and Income Generation Program. These programs can and must be expanded to bring the economy back to growth in the long run.

Keywords: COVID-19; economic crisis; informal work; unemployment; public policy.

\section{Pandemia e desemprego no Brasil}

A pandemia da COVID-19é um problema de saúde pública global que imprimiu uma nova dinâmica à economia mundial. A rápida propagação da doença e o uso do distanciamento como forma de prevenção expuseram as desigualdades sociais e urbanas das cidades capitalistas. No Brasil, como em outros países, o isolamento social promoveu rápidas mudanças no mercado de trabalho, com impactos mais severos para 37,3 milhões de pessoas que vivem na informalidade, já que elas não têm direitos como Fundo de Garantia por Tempo de Serviço (FGTS) e seguro-desemprego. Para a Organização Internacional do Trabalho (OIT), as primeiras demissões estão ocorrendo entre aqueles que vivem do trabalho precário, como terceirizados, balconistas, garçons, funcionários de cozinha, diaristas, manipuladores de bagagem e produtos de limpeza. Assim, faremos uma breve síntese das consequências que a crise sanitária vem promovendo para os trabalhadores brasileiros, bem como proporemos medidas de enfrentamento que não se limitem aos auxílios emergenciais. A recuperação e a criação de ocupações dependerão, entre outros fatores, da retomada dos gastos com programas sociais e econômicos que reduziram as desigualdades sociais no início deste século, como o Programa de Aceleração do Crescimento em Favelas (PAC-Favelas); o Programa Minha Casa, Minha Vida; o Programa Bolsa Família (PBF); e o Programa de Geração de Emprego e Renda (Proger) com recursos do Fundo de Amparo ao Trabalhador (FAT). Esses programas podem e devem ser ampliados a fim de fazer com a que a economia retome o crescimento em longo prazo.

Palavras-chave: COVID-19; crise econômica; trabalho informal; desemprego; políticas públicas.

\section{Pandemia y desempleo en Brasil}

La pandemia de COVID-19 es un problema de salud pública global que ha dado una nueva dinámica a la economía mundial. La rápida propagación de la enfermedad y el uso de la distancia como un medio de prevención expusieron las desigualdades sociales y urbanas de las ciudades capitalistas. En Brasil, como en otros países, el aislamiento social promovió cambios rápidos en el mercado laboral con impactos más severos para 37,3 millones de personas que viven en la informalidad, ya que no tienen derechos como el Fondo de Garantía por Tiempo de Trabajo y seguro de desempleo. Para la Organización Internacional del Trabajo, los primeros despidos ocurren entre quienes viven del trabajo precario, tales como: trabajadores subcontratados, vendedores de mostrador, camareros, personal de cocina, jornaleros, manipuladores de equipaje y productos de limpieza. Por lo tanto, haremos una breve síntesis de las consecuencias que la crisis sanitaria está promoviendo para los trabajadores brasileños, y propondremos medidas de afrontamiento que no se limiten a las ayudas de emergencia. La recuperación y la creación de ocupaciones dependerán, entre otros factores, de la reanudación de los gastos en programas sociales y económicos que redujeron las desigualdades sociales a principios de este siglo, como el Programa de Aceleración del Crecimiento (PAC Favelas); el "Programa Minha Casa, Minha Vida"; el "Programa Bolsa Família” y el Programa Fondo de Amparo al Trabajador (FAT). Esos programas pueden y deben expandirse para que la economía vuelva a crecer a largo plazo.

Palabras clave: COVID-19; crisis económica; trabajo informal; desempleo; políticas públicas. 


\section{INTRODUCTION}

On March 11, 2020, the World Health Organization (WHO) declared that a pandemic called COVID-19 was underway. The virus rapidly expanded around the world, with profound impacts on public health and unprecedented shocks on economies and labor markets. The preliminary assessment of the International Labour Organization (ILO), dated April 3, 2020, shows that more than 1 million people have been infected and that more than 50,000 have already lost their lives. In the case of Brazil, statistics from the Ministry of Health (MH) show that, as of July a 2, the country had 1,496,858 confirmed cases, of which 61,884 people had died july, ${ }^{1}$

The total or partial blockade measures, carried out by several countries to delay the spread of the disease, affected nearly 2.7 billion workers, representing about $81 \%$ of the world workforce (ILO, 2020). In the United States, for example, in early April 6.6 million workers applied for aid-unemployment. The speed and scale of job losses are unprecedented, as in just two weeks the pandemic has left nearly 10 million Americans unemployed (Casselman \& Cohen, 2020).

The challenge for countries requires a strategy that goes far beyond injecting liquidity into the economy and emergency aid for monetary resources to the most vulnerable in the short term. The situation requires the formulation and implementation of a post-pandemic economic development policy, that is, in the long term. The crisis revealed the weaknesses of the Brazilian economy, which was based on austerity, deindustrialization, informal work, the specialization of the production of primary goods for export and whose main buyer of commodities is China, where the epidemic began.

In addition to this external economic dependence, the Brazilian government has a strong barrier to improving the health system: the enactment of Constitutional Amendment No. 95 of 2016, which freezes public spending for 20 years. Thus, the health costs are not enabled to maintain the service network or allow investments for its improvement. In addition, programs such as More Doctors, Popular Pharmacy, distribution of medicines to chronic patients, among others, were dismantled. In a context of health crisis, it is verified that the country does not have sufficient resources to assist patient so diagnosed with COVID-19, because there is a lack of protective equipment such as masks, gloves, apron or goggles. Intensive Care Unit (ICU) beds and respirators are also not enough to serve the entire population.

With the budget frozen for 20 years, the damage to the Unified Health System (SUS) can exceed $\mathrm{R} \$ 400$ billion, says the president of the National Health Council (CNS), Fernando Pigatto, based on a study prepared by the Intersectoral Commission of Budget and Financing (Cofin) of the CNS. The SUS, which has always been underfunded, now faces an even worse situation, that of defunding, something that could have a serious impact on the life and health of the Brazilian population (CNS, 2020).

The freezing of spending, therefore, was already compromising the supply of public health services before the pandemic. With the stoppage of productive activities, the scenario tends to worsen, both due to the increased demand for new hospital beds for the treatment of coronavírus and the increase in unemployment. This is because workers who are fired, when they lose their income, can become delinquent and have their contracts canceled by health plans, over loading do the SUS.

\footnotetext{
${ }^{1}$ Retrieved from https://www.saude.gov.br/noticias/agencia-saude/47157-coronavirus-852-816-pessoas-estao-curadas-em-todo-o-brasil
} 
In view of these considerations, the objective of this work is to briefly present the consequences of COVID-19 for the Brazilian labor market, highlighting the impacts that the crisis promotes to workers living from informality, who have no help-illness, retirement or other benefits that protect them in situations of stoppage of productive activities. Next, we will present some social programs that the government can use to support the less favored with job and income generation, as well as improve the social and livability conditions of the population living in precarious settlements. The present moment requires the adoption of public policies that lead to the realization of the right to health and work.

\section{IMPACTS OF PANDEMIC ON THE BRAZILIAN LABOR MARKET}

Since 1990, with the loss of the dynamism of the national economy, the level of informality of the Brazilian labor market has increased. For Targino and Vasconcelos (2015), the formal sector of the labor market is one in which there is contract between employer and employee. This contract can be signed through the Consolidation of Labor Laws (CLT) or the Statute of the Public Servant. The informal sector, on the other hand, concerns workers who are deprived of basic or minimum working conditions and social protection (see Box 1).

The pandemic, in this context, affects with greater intensity the population living in informality and resides in precarious areas, that is, who have low and irregular incomes, without access to drinking water, decent housing, private health systems and social protection system linked to the signed work permit, such as vacation, minimum wage, 13th salary, Guarantee Fund for Service Time (FGTS),maternity leave, medical leave and insurance-unemployment. These workers meet long working hours and can hardly access financing lines for the legal exercise of the activity (Krein \& Proni, 2010). In 2009, informality in Brazil exceeded 50\%. In 2017, according to data from the Brazilian Institute of Geography and Statistics (IBGE), IBGE it was around 40.8\% (see Table 1).

\section{BOX 1 CLASSIFICATION OF OCCUPATIONS IN FORMAL AND INFORMAL}

\begin{tabular}{ll} 
Sector formal & \multicolumn{1}{c}{ Sector informal } \\
- Employees with a license & - Employees without a license \\
- Military & - Domestic workers without a license \\
- Statutory civil servants & - Own account \\
- Domestic workers with wallet & - Workers in production for their own consumption \\
- Employers with 6 or more employees & - Construction workers for the veryuse \\
& - Unpaid \\
\hline
\end{tabular}

Source: Targino and Vasconcelos (2015). 


\begin{tabular}{|c|c|c|c|c|c|c|}
\hline Proporção (\%) & 2012 & 2013 & 2014 & 2015 & 2016 & 2017 \\
\hline Formal & 58,5 & 59,7 & 60,9 & 61,0 & 60,9 & 59,2 \\
\hline Informal & 41,5 & 40,3 & 39,1 & 39,9 & 39,1 & 40,8 \\
\hline
\end{tabular}

Fonte: IBGE (2018).

In addition to the health crisis, one of the consequences of the pandemic is the increase in unemployment and, therefore, the increase in informalization of work, outsourced, subcontractors, flexibilizers, part-time workers and the sub proletariat. This population will need to be assisted with policies aimed at protecting them a from hunger and poverty, then is, need to be inserted into a social protection network. The challenge is phenomenal, given that one of the hallmarks of globalized and liberal capitalism - and which has been followed by the economic team of the Bolsonaro government - is the increasing informalization of labor, as Antunes (2009) explains.

Amid the computerization of work, the machine and digital world, we are knowing the informalization of work, outsourced, precarious, subcontractors, flexibilizers, part-time workers and the sub proletariat. If in the recent past the working class had levels of informality only marginally, today more than $50 \%$ of it is in this condition - here, informality is conceived in a broad sense-devoid of rights, outside the social protection network and without a work permit. Increased unemployment, exacerbated precariousness, sharp wage drawdown, increasing loss of rights - this is the most frequent design of the working class.

According to the ILO (2020), the impact on income-generating activities is especially severe for unprotected workers and the most vulnerable groups in the informal economy. What is happening in many countries, in addition to layoffs, is the reduction in working hours. In Brazil, as the problem, by the government, has been quite timid, the news reveals the growth in the number of layoffs in various sectors, with emphasis on services such as hotels, bars and restaurants (see Box 2).

BOX 2 SUMMARY OF NEWS ABOUT LAYOFFS IN BRAZIL

\begin{tabular}{ll} 
Date & \\
\hline March 26, 2020 & Hotels, bars and restaurants laid off 4,000 in the Federal District. \\
April 1, 2020 & Transport companies fire 145 in Rio Grande do Norte. \\
April 1, 2020 & CVC partner company (Porto Seguro/BA) closes and dismisses employees. ${ }^{1}$ \\
April 2, 2020 & Democratic shoe factory dismisses more than 1,000 employees in Ceará. ${ }^{2}$ \\
\hline
\end{tabular}




\begin{tabular}{|c|c|}
\hline Date & NEWS \\
\hline April 3, 2020 & Restaurant association says sector has already fired up to 800,000 in the country. ${ }^{3}$ \\
\hline April 3, 2020 & Gympass fires employees amid coronavirus pandemic (SP). ${ }^{4}$ \\
\hline April 4, 2020 & Hotels laid off 4,000 employees in Greater Recife. ${ }^{5}$ \\
\hline
\end{tabular}

1 Retrieved from https://www.poder360.com.br/coronavirus/empresa-parceira-da-cvc-demite-funcionarios-em-porto-seguro-assista/ 2 Retrieved from https:/g1.globo.com/ce/ceara/noticia/2020/04/02/fabrica-de-calcados-democrata-demite-mais-de-mil-funcionariosem-unidade-do-ceara-meio-a-crise-da-covid-19.ghtml

3 Retrieved from https:/exame.abril.com.br/economia/associacao-de-restaurantes-diz-que-setor-ja-demitiu-ate-800-mil-no-pais/

4 Retrieved from https://valorinveste.globo.com/objetivo/empreenda-se/noticia/2020/04/03/gympass-demite-funcionarios-em-meioa-pandemia-de-coronavirus.ghtml

5 Retrieved from https://g1.globo.com/pe/pernambuco/noticia/2020/04/04/pandemia-de-coronavirus-afeta-rede-hoteleira-diminuiocupacao-e-ocasiona-demissoes-em-pernambuco.ghtml

Source: Elaborated by the author.

To face the crisis, the Brazilian government created the Emergency Program for the Maintenance of Employment and Income, through Provisional Measure No. 936, of 2020, betting on the "reduction of working hours and, proportionally, of salary, by written individual agreement or collective bargaining and with a maximum duration of 90 days". However, the program, in addition to making labor relations precarious, is aimed only at formal workers in the private sector and will have a negative impact on the mass of wages paid in this sector, due to the loss of individual wage income. Thus, "the rate of replacement of wages is only integral to the minimum wage, being between $90 \%$ and $70 \%$ for salaries up to $3 \mathrm{Mw}$ " (Departamento Intersindical de Estatística e Estudos Socioeconômicos [Dieese], 2020). On the other hand, "the guarantee of employment is only valid for workers directly affected by the reduction of the work day or the suspension of the employment contract. The other employees of the company can be dismissed" (Dieese, 2020).

According to the ILO forecast, in Brazil, the sectors most affected by the coronavirus crisis have been those operating in retail, accommodation and food services and manufacturing. To reverse this situation and overcome future challenges, it is necessary to review both Constitutional Amendment No. 95 which instituted the of expenses, how much of the Labor Reform, in order to avoid the growth of precariousness. The Reform worsened the worker's life and increased the number of precarious contracts, as well as insecurity, making him more dependent on the government's social programs.

The reform established a menu of precarious employment contracts, either due to insufficient hours worked or the possibility of reducing rights; changed the length of the working day through various mechanisms, including individual negotiation; reduced guarantees on salary, holidays, wage isonomy and protection for lactating women; included measures that facilitate dismissal and reduce the possibility for workers to claim their labor rights in labor court. In addition, it approved points with negative repercussions on the trade union organization and the collective bargaining process (Dieese, 2019). 


\section{PANDEMIC AND UNEMPLOYMENT: PROPOSALS TO COPE}

As we have previously addressed, the economic crisis resulting from coronavirus has been destroying several jobs in Brazil and abroad. The urgency of the situation requires the adoption of public employment and income transfer policies to protect workers who live informally while activities are paralyzed. In the long run, however, the country needs a development policy that involves abandoning fiscal austerity and increasing spending on existing social programs to protect millions of workers living in informality and living in precarious communities or settlements, not to mention the homeless population.

The pandemic showed, for example, two serious problems that prevent the fight against the disease in Brazilian slums: the absence of basic sanitation and the high density of human beings per square meter. Thus, directing resources to health and the sectors identified as bottlenecks is essential to boost the economy with the generation of formal jobs. In fact, the crisis has brought an important signal to the public and private sectors with regard to investment decisions in expanding production capacity.

In this context, it is necessary to increase public and private investments in the area of health, basic sanitation, popular housing and urban infrastructure. According to the World Bank (2018), "Brazil has invested about $2 \%$ of GDP in infrastructure, much less than similar countries around the world, and not even enough to cover depreciation. A growing focus should be given to improving the quality and sustainability of infrastructure." In addition to creating jobs, actions in this area could reduce risks and threats related to minimum standards of hygiene and health in needy communities. This is important because, in a country where basic sanitation has not been universalized, it is difficult to demand social isolation from an extensive population that has no piped water or financial resources to buy soap and alcohol gel. As precarious settlements need urbanization and the resident population needs employment, one measure to cope with the crisis is to increase resources for investment in housing of social interest through development banks.

In this context, it is necessary to increase public and private investments in the area of health, basic sanitation, popular housing and urban infrastructure. According to the World Bank (2018), "Brazil has invested about $2 \%$ of GDP in infrastructure, much less than similar countries around the world, and not even enough to cover depreciation. A growing focus should be given to improving the quality and sustainability of infrastructure." In addition to creating jobs, actions in this area could reduce risks and threats related to minimum standards of hygiene and health in needy communities. This is important because, in a country where basic sanitation has not been universalized, it is difficult to demand social isolation from an extensive population that has no piped water or financial resources to buy soap and alcohol gel. As precarious settlements need urbanization and the resident population needs employment, one measure to cope with the crisis is to increase resources for investment in housing of social interest through development banks.

Construction, or constructbusiness is not just about construction companies and developers; it is much broader. Starting with the work of studies and feasibilities of an enterprise, it covers various services, engineers, architects, people responsible for the approval of projects in public agencies, managers, among others. Passing through the workers of the sector, it extends to real estate agents, brokers, and brings together suppliers of materials (industry) and other sectors, such as automotive, furniture, electronics and security (Oliveira, 2019). 
In addition to investments in urban and social infrastructure, in the context of post-COVID-19, the government will need to increase spending on social programs and income transfer policies, which will be essential to face poverty and guarantee the intertemporal allocation of consumption through the life cycle, functioning as a social insurance. This, however, is a challenge for a government that has as a priority to reduce the size of the state in the economy. In his first year in office, for example, President Jair Bolsonaro increased spending on investments and costing of the machine for the defense area, while reducing spending for education, health and safety. With the crisis underway, the government's priorities need to be reviewed.

According to The Forum Magazine, social programs are not considered a priority in the Bolsonaro government, given that, at the end of 2019, there were reductions in the budget in both the My House, My Life and Bolsa Familia Program (PBF). The average resources allocated to the housing program was R $\$ 11.3$ billion per year between 2009 and 2018. By July 2019, however, Minha Casa had received $\mathrm{R} \$ 2.6$ billion from the Treasury. The R $\$ 30$ billion allocated to the PBF in 2020 did not change. As there was no correction by inflation, these resources will no longer benefit the 13.8 million households, reducing the benefit to only 13.2 million households.

Amid the COVID-19 crisis, while almost all countries affected by the epidemic are expanding social policies to address the repercussions of the disease in the economy, the Bolsonaro government intended to reduce in March 2020 the resources allocated to the PBF, the most efficient program to combat poverty. The Northeast, one of the least developed regions, would be the most affected - the government intended to reduce 158,000 benefits, totaling $61.1 \%$ of the region. Fortunately, this decision was reviewed by the Supreme Court (STF), which ordered the suspension of cuts in the PBF while the state of public calamity resulting from the pandemic persists. For Minister Marco Aurélio, it is necessary to treat all states in an isonomic way: "When the situation is normalized in the country, the liberalization of resources for new enrollment in the program should occur uniformly among the states of the Federation, without any kind of discrimination" (Supremo Tribunal Federal, 2020).

Finally, the government has at its disposal several programs focused on the social and economic field that were able to reduce social inequalities at the beginning of this century, such as the CAP; the My House, My Life Program; the PBF and the Employment and Income Generation Program (Proger), with resources from the Worker Support Fund. ${ }^{2}$ These programs can and should be expanded in order to get the economy to resume its long-term growth.

\section{CONCLUSION}

This research aimed to show, in a summarized way, how the new coronavirus produces profound impacts on public health and the Brazilian labor market. In a context of shutdown of productive activities, informal workers have lost their livelihoods, and many companies have already begun to lay off employees with a signed license. With this, it is expected to increase in the informality rate of the Brazilian economy, which is currently around $40.8 \%$. Moreover, with the drop-in employment

\footnotetext{
${ }^{2}$ Proger-FAT is a set of financing lines created with the purpose of increasing public policy to combat unemployment, through financing focused on smaller enterprises in various sectors of the economy, with emphasis on tourism, export and technological innovation. The program also allocates resources for lines aimed at improving the quality of life and employability of workers and for family farming.
} 
and the increase in delinquency, the subsequent cancellation of health plans will tend to burden the already disabled SUS.

The Brazilian government has been responding very timidly to the problems arising from the crisis and is going on a path that does not contribute to a quick exit from it. Formal and informal workers need social programs that generate employment and income, promote an improvement in the living conditions of communities and precarious settlements, and need social protection.

In this current context, the exit from the crisis demands the abandonment of austerity and calls for the injection of resources for health and sectors identified as bottlenecks. As precarious settlements need urbanization and the resident population needs employment, one measure to cope with the crisis is to increase resources for investment in housing of social interest through development banks. These measures contribute to improving the health and quality of life of the poorest population, as well as leveraging several other sectors of the economy, such as construction.

Inevitably, all resources focused on financing these programs will widen the public deficit. But in the long run, with the resumption of growth and jobs, there will be an increase in GDP and an increase in revenues. Similarly, many communities can benefit from urbanization projects and will be better prepared to face epidemic crises such as the one the world is currently experiencing. The length of time the crisis will therefore depend on the political choices of the current government. 


\section{REFERENCES}

Antunes, R. (2009). Os sentidos do trabalho: ensaio sobre a formação e a negação do trabalho. São Paulo, SP: Boitempo.

Banco Mundial. (2018, August 23). Notas de políticas públicas - Por um ajuste justo com crescimento compartilhado. INFORMATIVO | 23 de agosto de 2018. Retrieved from https://www.worldbank.org/ pt/country/brazil/brief/brazil-policy-notes

Casselman, B., \& Cohen, P. (2020, April 02). A widening toll on jobs: this thing is going to come for us all. The New York Times. Retrieved from https:// www.nytimes.com/2020/04/02/business/economy/ coronavirus-unemployment-claims.html

Cicantell, P., \& Smith, D. (2005). Nature, raw materials, and political economy: an introduction. In P. Cicantell, D. Smith, \& G. Seidman. Nature, raw materials, and political economy. London, UK: Elsevier.

Conselho Nacional de Saúde. (2020, February 28). Saúde perdeu $R \$ 20$ bilhões em 2019 por causa da EC 95/2016. Brasília, DF: Ministério da Saúde. Retrieved from https://conselho.saude.gov.br/ultimas-noticiascns/1044-saude-perdeu-r-20-bilhoes-em-2019-porcausa-da-ec-95-2016

Departamento Intersindical de Estatística e Estudos Socioeconômicos. (2018, March). Precarização do trabalho avança sobre setores e ocupações mais estruturadas. Boletim Emprego em Pauta, 7, 1-4. Retrieved from https://www. dieese.org.br/boletimempregoempauta/2018/ boletimEmpregoEmPauta7.html

Departamento Intersindical de Estatística e Estudos Socioeconômicos. (2019, November). O novo desmonte dos direitos trabalhistas. Nota Técnica, 215, 1-10. Retrieved from https://www.dieese.org. br/notatecnica/2019/notaTec215MP905.html

Departamento Intersindical de Estatística e Estudos Socioeconômicos. (2020, April 03). O Programa Emergencial de Manutenção do Emprego e da Renda diante dos impactos da Covid-19. Nota Técnica, 232, 1-13. Retrieved from https://www.dieese.org.br/notatecnica/2020/ notaTec232ProgramaEmergencialGoverno/index. html?page $=1$

Furtado, C. (1992).Brasil:aconstruçãointerrompida. Rio de Janeiro, RJ: Paze Terra.

Instituto Brasileiro de Geografia e Estatística. (2018). Síntese de indicadores sociais: uma análise das condições de vida da população brasileira (Estudos e pesquisas. Informação demográfica e socioeconômica, n. 39). Rio de Janeiro, RJ: Author. Retrieved from https://biblioteca.ibge.gov.br/ visualizacao/livros/liv101629.pdf

International Labour Organization. (2020, April 07). ILO Monitor: Covid-19 and the world of work. Second Edition. Updated estimates and analysis. Genebra, Switzerland: Author. Retrieved from https://www.ilo.org/wcmsp5/groups/public/@ dgreports/@dcomm/documents/briefingnote/ wcms_740877.pdf

Krein, J. D., \& Proni, M. W. (2010). Economia informal: aspectos conceituais e teóricos. Brasília, DF, OIT.

Mathias, M., \& Torres, R. (2020, April 02). O coronavírus encontra um país devastado. Outra Saúde. Retrieved from https://outraspalavras.net/ outrasaude/o-coronavirus-encontra-um-paisdevastado/

Ministério da Economia. (2020, April 01). Governo lança Programa Emergencial de Manutenção do Emprego para enfrentar efeitos econômicos da Covid-19. Brasília, DF: Author. Retrieved from https://www.gov.br/economia/pt-br/assuntos/ noticias/2020/abril/governo-lanca-programaemergencial-de-manutencao-do-emprego-paraenfrentar-efeitos-economicos-da-covid-19

Oliveira, F., Filho. (2019, December 01). Construção civil, a locomotiva da economia. Campinas, SP: Documento AcidadeOn. Retrieved from https://www.acidadeon.com/campinas/ docon/artigos/NOT, $0,0,1464132$, construcao $+\mathrm{c}$ ivil+a+locomotiva+da+economia.aspx

Supremo Tribunal Federal. (2020, March 23). Ministro Marco Aurélio suspende cortes no Bolsa Família durante pandemia. Brasília, DF: Author. Retrieved from http://stf.jus.br/portal/cms/ vernoticiadetalhe.asp? Id conteudo=439926

Revista Fórum. (2019, September 03). Com corte de recursos, Bolsonaro inicia desmonte de Bolsa Família, Minha Casa Minha Vida e Fies. Retrieved from https://revistaforum.com.br/politica/bolsonaro/ com-corte-de-recursos-bolsonaro-incia-desmontedo-bolsa-familia-minha-casa-minha-vida-e-fies/

Vasconcelos, E. A. S. de, \& Targino, I. (2015, January/ June). Informalidade no mercado de trabalho brasileiro (1993-2013). Revista da Abet, 14(1), 141161. Retrieved from https://periodicos.ufpb.br/ index.php/abet/article/view/25705/13881 


\section{Simone da Silva Costa}

https://orcid.org/0000-0001-7347-7617

Ph.D. in Architecture and Urbanism from the Federal University of Rio Grande do Norte (UFRN); Distance tutor at Federal University of Rio Grande do Norte (UFRN); Researcher at the National Council for Scientific and Technological Development $(\mathrm{CNPq})$ in the research project led by the Department of Architecture and Urbanism by the Federal University of Rio Grande do Norte (UFRN). E-mail: simoneufrnap37@gmail.com 